\title{
Hubungan Dukungan Sosial dengan Kecemasan dan Depresi pada Pasien Kanker Payudara di RSU Raden Mattaher Jambi
}

\author{
Yuliana $^{1^{*}}$, Mustikasari ${ }^{2}$, Feri Fernandes ${ }^{3}$ \\ ${ }^{1}$ Mahasiswa S2 Keperawatan Universitas Andalas \\ ${ }^{2}$ Staf Pengajar Fakultas Kedokteran Universitas Andalas \\ ${ }^{3}$ Staf Pengajar Fakultas Keperawatan Universitas Andalas \\ *Correspondence email: anayuli561@yahoo.co.id
}

\begin{abstract}
Abstrak. Kanker payudara merupakan kanker yang paling sering ditemui pada wanita. Di Eropa kurang lebih 175.000 kasus dan lebih dari 165.000 pasien meninggal jika tidak dikendalikan. Sedangkan di Amerika Serikat 44.000 pasien meninggal karena penyakit kanker payudara. Menurut Statistik Rumah Sakit dalam Sistem Informasi Rumah Sakit kanker payudara menempati urutan pertama pada pasien rawat inap di seluruh rumah sakit di Indonesia. Dampak kanker payudara terhadap aspek bio-psikososia-spritual pada penderita kanker payudara diantaranya adalah kecemasan dan depresi. Sayangnya penelitian ini sedikit dilakukan oleh penelitian. Salah satu upaya untuk menurunkan kecemasan dan depresi pada pasien kanker payudara adalah dengan memberikan dukungan sosial. Penelitian ini bertujuan untuk mengetahui hubungan dukungan sosial dengan kecemasan dan depresi pada pasien kanker payudara. Metode yang digunakan adalah analitik crossectional Study. yang dilakukan di RSU Raden Mattaher Jambi terhadap 97 pasien. Dengan metode pengambilan sampel Insidental Sampling. Metode pengumpulan data dengan menggunakan Instrumen Multidimensional Scale of Perceived of Sosial Suport (MSPSS), dan Hospital Anxiety and Depression Scale (HADS), Analisa Bivariat menggunakan uji Chi Square. Hasil penelitian menunjukkan bahwa Usia pasien kanker payudara rata-rata $(46,57)$, Lama terdiagnosis $(28,59)$ bulan, Tingkat pendidikan Rendah $(68,0 \%)$, Status Perkawinan Kawin (91,8\%), Penggunaan Kontrasepsi Oral (91,8\%), Status Pekerjaan tidak bekerja (78,4\%), Dukungan sosial baik $(54,6 \%)$, Cemas (49,5\%), Depresi (50,5\%), ada hubugan dukungan sosial dengan kecemasan pada pasein kanker payudara $(\mathrm{p}=0,000)$, ada hubungan dukungan sosial dengan depresi pada pasien kanker payudara $(\mathrm{p}=0,000)$.
\end{abstract}

Kata Kunci: dukungan sosial; kecemasan; depresi

Abstrack. Breast cancer is the most common cancer in woman. In Europen there are approximately 175,000 cases found regarding breast cancer and more than 165,000 patients died if the cancer is not controlled, whereas in the United States 44,000 patients died of breast cancer. According to the Hospital Statistics in the Breast Cancer Hospital Information System, Indonesia is the first rank of the most breast cancer patients which can be found in almost every hospital in Indonesia. The impact of breast cancer on the aspects of bio-psycho-social-spritual in breast cancer patients include anxiety and depression.Unfortunately this study is not commonly carried aut by researchers. One effort to reduce anxiety and depression in breast cancer patients is to provide social support. This study aims to determine the relationship of social support with anxiety and depression in breast cancer patients. The method used is analytic cross- sectional study.Also this study is conducted at Raden Mattaher Hospital in Jambi, with 97 breast cancer patients were picked as participants. Data sampling that is utilised in this study was incidental sampling.The data were colleted by using several methods, such as the Multidemensional Scale of Perceived of Social Support (MSPSS) instrument, and the Hospital Anxiety and depression Scale (HADS), and later those data were analysed with Bivariate Analysis using the Chi Square test. The results showed that the average age of breast cancer patient is 46,57, length of diagnosis is 28,59 months, low education level patient is 68,0\%, patient who has merried is 91,8\%, unemployed patient is 78,4\%, patient who reseived good social support is 54,6\%, patient with anxiety is 49,5\%, and patient with depression is 50,5\%. There is relationship between social support and anxiety in breast cancer patients, with (p:0,000).

Keyword: social support; worry; depression

\section{PENDAHULUAN}

Kanker payudara merupakan kanker yang paling sering ditemui pada wanita, Prevalensi kejadian 8 - 9\% wanita akan mengalami kanker payudara. Lebih dari 250. 000 kasus baru kanker payudara terdiagnosa pada setiap tahun, di Eropa kurang lebih 175.000 kasus dan lebih dari 165.000 pasien meninggal jika tidak dikendalikan. Di Amerika Serikat 44.000 pasien meninggal karena penyakit kanker payudara (WHO dalam Mulyani, 2013).

Menurut Statistik Rumah Sakit dalam Sistem Informasi Rumah Sakit kanker payudara menempati urutan pertama pada pasien rawat inap di seluruh rumah sakit di Indonesia (DepKes RI, 2013). Indonesia, setiap tahun diperkirakan terdapat 100 penderita kanker payudara per 100.000 penduduk.

Dampak kanker payudara terhadap aspek biopsiko-sosia-spritual pada penderita kanker payudara di dua rumah sakit besar di Jakarta menunjukkan bahwa penderita kanker payudara mengekspresikan ketidakberdayaan, merasa tidak sempurna, merasa malu dengan bentuk payudara, ketidak bahagian, merasa tidak menarik lagi, perasaan kurang diterima oleh orang lain, merasa terisolasi, takut, berduka, berlama-lama ditempat 
tidur, ketidak- mampuan fungsional, gagal memenuhi kebutuhan keluarga, kurang tidur, sulit berkonsentrasi, kecemasan, dan jika berlanjut dapat menyebabkan depresi. Brunner \& Suddarth (2010).

Perubahan yang terjadi dapat mempengaruhi kondisi psikologis klien. Menurut penelitian Hong \& Tian (2014) diperoleh hasil bahwa pasien yang menderita penyakit kanker payudara mengalami kecemasan dan depresi dengan hasil $60,62 \%$ prevalensi mengalami depresi dan $66,72 \%$ mengalami kecemasan

Salah satu upaya untuk menurunkan kecemasan dan depresi pada pasien kanker payudara adalah dengan memberikan dukungan sosial yang dapat memberikan perhatian, pengertian, penghargaan dan dukungan emosioanal. (Nasir, 2011).

\section{METODE}

Penelitian ini menggunakan desain analitik crossectional yang bertujuan menganalisis hubungan dukungan sosial dengan kecemasan dan depresi pada pasien kanker payudara di RSU Raden Mattaher Jambi.

\section{HASIL DAN PEMBAHASAN Hasil}

Penelitian ini dilakukan di RSU Raden Mattaher Jambi dengan sampel sebanyak 97 orang. Hasil penelitian menunjukkan bahwa rata-rata usia kanker payudara $(44,65)$ tahun, Lama terdiagnosis $(28,59)$ bulan, Tingkat pendidikan rendah $(68,0 \%)$, Status perkawinan kawin $(91,8 \%)$, Pengguanaan kontrasepsi oral $(91,8 \%)$, Status Pekerjaan tidak bekerja $(78,4 \%)$, Dukungan sosial baik $(54,6 \%)$, Tingkat cemas $(49,5 \%)$, depresi $(50,5 \%)$. usia klien secara rata-rata adalah 46,57 tahun $(95 \% 44,49: 48,64)$. Umur termuda 20 tahun dan umur tertua 70 tahun. Hasil estimasi interval dapat disimpulkan bahwa 95\% diyakini umur responden adalah diantara 44,49 sampai dengan 48,64 tahun. Lama terdiagnosis kanker adalah 28,59 tahun (95\% CI 24,86:32,31). klien kanker payudara sebagian besar berpendidikan rendah $(68,0 \%)$, berstatus kawin $(91,8 \%)$, Menggunakan kontrasepsi oral $(91,8 \%)$, tidak bekerja $(78,4 \%)$. dukungan sosial baik $(54,6 \%)$, cemas $(49,5 \%)$, dan depresi $(50,5 \%)$.

Tabel 1. Hubungan Dukungan Sosial dengan Kecemasan pada pasien Kanker Payudara di RSU Raden Mattaher Jambi

\begin{tabular}{lcccccccc}
\hline \multicolumn{2}{c}{ Dukungan Sosial } & $\begin{array}{l}\text { Kecemasan } \\
\text { Tidak Cemas }\end{array}$ & \multicolumn{2}{c}{ Cemas } & & Total & & OR \\
\hline & $\mathrm{N}$ & $\%$ & $\mathrm{n}$ & $\%$ & $\mathrm{n}$ & $\%$ & Value \\
Baik & 41 & $77,4 \%$ & 12 & $22,6 \%$ & 49 & 100 & 15,375 & 0,000 \\
Tidak Baik & 8 & $18,2 \%$ & 36 & $81,8 \%$ & 48 & 100 & \\
$\quad$ Jumlah & 49 & $50,5 \%$ & 48 & $49,5 \%$ & 97 & 100 & \\
\hline
\end{tabular}

Berdasarkan tabel 1 didapatkan hasil analisis antara dukungan sosial dengan kecemasan diperoleh bahwa ada sebanyak $12(22,6 \%)$ responden mengalami kecemasan. Sedangkan dukungan sosial tidak baik 36 $(81,8 \%)$ mengalami kecemasan. Hasil uji statistik diperoleh nilai $\mathrm{p}=0,000$ maka dapat disimpulkan ada perbedaan dukungan sosial baik dengan kecemasan (ada hubungan yang signifikan antara dukungan sosial dengan kecemasan). Dari hasil analisis diperoleh pula nilai $\mathrm{OR}=15,375$ artinya dukungan sosial tidak baik mempunyai peluang 15,375 kali mengalami kecemasan dibanding dengan dukungan sosial baik.

Tabel 2. Hubungan Dukungan Sosial dengan Depresi pada pasien Kanker Payudara di RSU Raden Mattaher Jambi

\begin{tabular}{lcccccccc}
\hline Dukungan Sosial & $\begin{array}{l}\text { Depresi } \\
\text { Tidak depresi }\end{array}$ & \multicolumn{3}{c}{ Total } & & OR & P value \\
\hline & $\mathrm{n}$ & $\%$ & $\mathrm{n}$ & $\%$ & $\mathrm{~N}$ & $\%$ & 13.8000 \\
Baik & 46 & $86,8 \%$ & 7 & $13,2 \%$ & 53 & 100 & 0,000 \\
Tidak Baik & 2 & $4,5 \%$ & 42 & $95,5 \%$ & 44 & 100 & \\
Jumlah & 48 & $49,5 \%$ & 49 & $50,5 \%$ & 97 & 100 & \\
\hline
\end{tabular}

Hasil analisis antara dukungan sosial dengan depresi diperoleh bahwa ada sebanyak $7 \quad(13,2 \%)$ responden mengalami depresi. Sedangkan dukungan sosial tidak baik $42(95,5 \%)$ mengalami depresi. Hasil uji statistik diperoleh nilai $\mathrm{p}=0,000$ maka dapat disimpulkan ada perbedaan dukungan sosial baik dengan depresi (ada hubungan yang signifikan antara dukungan sosial dengan depresi). Dari hasil analisis diperoleh pula nilai $\mathrm{OR}=13.8000$, artinya dukungan sosial tidak baik mempunyai peluang 13.8000 kali mengalami depresi dibanding dengan dukungan sosial baik

\section{Pembahasan}

Dukungan sosial adalah orang lain yang akan berinteraksi dengan individu sehingga individu tersebut dapat merasakan kenyamanan fisik maupun psikologis. Dukungan sosial ini dapat diperoleh dari pasangan hidup, orang tua, saudara, anak, kerabat, teman, rekan kerja, staf medis, serta anggota kelompok kemasyarakatan. individu dengan dukungan sosial yakni bahwa mereka dicintai dan diperhatikan, dihargai dan berarti sebagai bagian dari jaringan sosial, seperti keluarga atau organisasi masyarakat, yang dapat 
Yuliana et al, Hubungan Dukungan Sosial dengan Kecemasan dan Depresi pada Pasien Kanker Payudara di RSU Raden Mattaher Jambi

memberikan pertolongan, jasa dan pelayanan satu sama lain, terutama pada saat yang dibutuhkan (Neufeld, 2010). Berdasarkan hasil penelitian terdapat hubungan dukungan sosial dengan kecemasan dan depresi pada pasien kanker payudara. Menurut penelitian Maeda dkk (2013) dukungan sosial, terutama dukungan dari keluarga merupakan faktor yang signifikan dalam penurunan kecemasan dan depresi pada pasien kanker payudara. Hasil penelitian dari Maeda menunjukkan bahwa kurangnya dukungan dari keluarga berhubungan signifikan dengan peningkatan kecemasan dan depresi. Berdasarkan analisa peneliti semakin baik dukungan sosial yang diberikan maka semakin berkurang kecemasan dan depresi pada pasien kanker payudara. Oleh sebab itu diharapkan keluarga untuk memberikan dukungan emosional berupa perasaan nyaman, aman, dan dicintai terutama pada saat penuh tekanan, bentuk dukungan ini membuat individu memiliki perasaan nyaman, yakin, dipedulikan dan dicintai oleh sumber dukungan sosial sehingga individu dapat menghadapi masalah dengan lebih baik. Dukungan ini sangat penting dalam menghadapi keadaan yang dianggap tidak dapat dikontrol (Victoria, et al., 2011).

\section{SIMPULAN}

Berdasarkan hasil penelitian dapat disimpulkan bahwa terdapat hubungan dukungan sosial dengan kecemasan dan depresi pada pasien kanker payudara di RSU Raden Mattaher Jambi.

\section{Saran}

Pihak RSU Raden Mattaher Jambi mengembangkan pelayanan kesehatan jiwa yang terintegrasi dalam pelayanan keperawatan dalam upaya meningkatkan kualitas asuhan keperawatan jiwa, khususnya pada klien kanker payudara, dapat melakukan tindak lanjut hasil penelitian ini dengan mengembangkan pelayanan kesehatan jiwa yang terintegrasi dalam pelayanan keperawatan pada klien yang mengalami masalah psikososial khususnya kecemasan dan depresi. Bagi Perawat diharapkan memberikan psikoedukasi kepada keluarga dan klien tentang pentingnya dukungan sosial terhadap klien dalam menjalani terapi misalnya menanyakan keadaan klien pada saat datang ke Rumah Sakit. sehingga dapat mengurangi kecemasan dan depresi pada klien kanker payudara. Hasil penelitian ini diharapkan dapat menjadi tambahan informasi dan bahan pengajaran mata kuliah keperawatan jiwa sehingga mahasiswa mengetahui pentingnya pemberian dukungan sosial pada pasien kanker payudara yang terkait dengan penanganan klien cemas dan depresi. Bagi ilmu keperawatan perlu adanya penelitian lebih lanjut berupa Penelitian Quasi eksperimental tentang Hubungan spritual dengan kecemasan dan depresi pada pasien kanker payudara.

\section{DAFTAR PUSTAKA}

Abdul, N \& Abdul, M. (2011). Dasar-Dasar Keperawatan Jiwa: Pengantar dan Teori. Jakarta: Salemba Medika

Alphonse, G.T, Barbara, L.S \& John, K.E. (2010). Breast Cancer: A Multidisiplinary Approach To Diagnosis and Management. Nort American: Demos Medical Publishing

Antonio, G \& Nicola, M. (2009). Breast Cancer In The Post-Genomic Era. London: Humana Press

Barker, P. (2009). Psychiatric and Mental Health Nursing; The Craft of Caring. London: Edward Arnold Publisher

Chaterine, (2014). Influence of Patient and Treatmen Factors on Adherence to Adjuvant Endocrine Therapy in breast cancer.Onkology Nursing Society. Diakses pada tanggal 15 Maret 2015

Christine, (2012) Dukungan Keluarga Terhadap Harga Diri Pasien Kanker Payudara DI RSUP H Adam Malik Medan. Diakses Pada tanggal 19 September 2015

Han, Yan, Zhang, Zhao, Sun, Li, Lei, Liu, \& Cen. (2014). The Influence Of The Social Support On Symptoms Of Anxiety And Depression Among Patients With Silicosis. China. The Scientific Word Journal. Volume 2014, Article ID 724804, 6 Page. Diunduh Melalui http://dx.doi.org/10.1155/2014/724804. Diakses pada tanggal 14 Maret 2015

Hastono,P, S (2007). Analisis Data Kesehatan. Fakultas Kesehatan Masyarakat: Universitas Indonesia

Hong \& Tian. (2014). Prevalence Of Anxiety And Depression And Their Risk Factors In Chinese Cancer Patients. Verlag Berlin. Journal Of Support Care Cancer. DOI10.1007/s00520-0131997-y. Diakses pada tanggal 14 Mei 2015

Lueboonthavatchai,MD (2007). Prevalence and Psychosocial Factors Of Anxiety and Depression in Breast Cancer Patients.Bangkok.e-Journal J Med Assoc Thai Vol.90.No 10 2007. http:// www.medassocthai.org/journal. Diakses pada tanggal 14 maret 2015

Lubis, N. L. Dkk. (2009). Terapi Perilaku Kognitif Pada Pasien Kanker . Medan: USU Press

Lubis, N. L, (2009). Dukungan Sosial Pada Pasien Kanker Pada Pasien Kanker, Perlukah, USU Press. Medan Indonesia

Neufeld, A \& Harrison,M. (2010). Nursing And Family Caregiving Social Support And Nonsupport. New York: Springer Publishing Company, LLC

Notoatmojo. (2010). Metodologi penelitian. Jakarta: Rineka Cipta

Manoj, P, Gangadharan, P.S, Nandkumar, D, Bejoy, C.T, Badridien, M.H, \& Rita, K. (2006).Distress, Anxiety, and depression in Cancer Patients Undergoing Chemotherapy. World Journal Of Surgical Oncology. Diunduh dari 
Yuliana et al, Hubungan Dukungan Sosial dengan Kecemasan dan Depresi pada Pasien Kanker Payudara di RSU Raden Mattaher Jambi

http://www.wjso.com/content/4/1/68. Diakses pada tanggal 16 Maret 2015

Maeda, Morishima, Ueno, Umemoto \& Sasaki. (2014). The Predictors Of Psychological Status Among Primary Breast Cancer Patients In Japan. Japan. Open Journal Of Nursing, 2014. Diunduh melalui http://dx.doi.org/10.4236/ojn.2014.43022. Diakses pada tanggal 21 Mei 2015

Sarafino, E.P. (2006). Health Psychology: Biopsychosocial Interaction. $5^{\text {th }}$ edition. United States Of America: Jhon Willey \& Sons, Inc

Stuart, G.W (2013). Principles and Practice of Psychiatric Nursing. (7th ed). St. Louis: Mosby Year

Townsend, M.C. (2009). Essentials Of Psychiatric Mental Health Nursing. (3rd ed) Philadephia: F.A. Davis Company

Videbeck, S.L. (2008). Buku Ajar Keperawatan Jiwa (Psychiatric Mental Health Nursing). Jakarta : EGC 